\title{
Determination of Polyphenols Content in Carob Pulp from Wild and Domesticated Moroccan Trees
}

\author{
Brahim El Bouzdoudi1, Zineb Nejjar El Ansari1 ${ }^{*}$, Ionel Mangalagiu², Dorina Mantu², \\ Alain Badoc ${ }^{3}$, Ahmed Lamarti ${ }^{1}$
}

${ }^{1}$ Laboratory of Plant Biotechnology, Biology Department, Faculty of Sciences, Abdelmalek Essaadi University, Tetouan, Morocco

${ }^{2}$ Laboratory of Chemical Structure Analysis, Organic Chemistry Department, Faculty of chemistry, "Alexandru Ioan Cuza”

University, Iasi, Romania

${ }^{3}$ Axe MIB (Molécules d'Intérêt Biologique), Unité de Recherche EEnologie EA 4577, USC 1366 INRA, UFR des Sciences Pharmaceutiques, Université de Bordeaux, ISVV (Institut des Sciences de la Vigne et du Vin), Villenave-d'Ornon, France

Email: *zinebnejjarelansari@hotmail.com

How to cite this paper: El Bouzdoudi, B. El Ansari, Z.N., Mangalagiu, I., Mantu, D., Badoc, A. and Lamarti, A. (2016) Determination of Polyphenols Content in Carob Pulp from Wild and Domesticated Moroccan Trees. American Journal of Plant Sciences, 7, 1937-1951.

http://dx.doi.org/10.4236/ajps.2016.714177

Received: September 1, 2016

Accepted: October 8, 2016

Published: October 11, 2016

Copyright $\odot 2016$ by authors and Scientific Research Publishing Inc. This work is licensed under the Creative Commons Attribution International

License (CC BY 4.0).

http://creativecommons.org/licenses/by/4.0/

\begin{abstract}
Carob (Ceratonia siliqua L.) fruit pulp from 12 wild and 8 domesticated trees from 15 Moroccan localities were investigated for their polyphenols contents: total polyphenols content $(53.22-118.04 \mathrm{mg}$ and $57.46-183.31 \mathrm{mg}$ ), total flavonoids (1.41 $4.83 \mathrm{mg}$ and $1.62-7.46 \mathrm{mg}$ ) and condensed tannins (1.47 - $7.36 \mathrm{mg}$ and $1.85-6.66$ $\mathrm{mg}$ ) in one carob fresh pulp for wild and domesticated trees, respectively. Fruit pulp from trees in the same region shows variable contents in polyphenols, flavonoids and condensed tannins.
\end{abstract}

\section{Keywords}

Ceratonia siliqua L., Carob Pulp, Wild Tree, Domesticated Tree, Polyphenols

\section{Introduction}

Ceratonia siliqua L. (carob tree) is a perennial Fabaceous tree which is flourishing in the Mediterranean area since antiquity [1] [2]. It grows usually in mild and dry places with marginal and prevailing calcareous soils [1]. The tree attains a mature height and spread of $6-12 \mathrm{~m}$, and sometimes more than $20 \mathrm{~m}$, with branches extended to ground level [3].

Carob pod is the fruit of carob tree and is mostly used in the food industry for locust bean gum: polysaccharides (galactomannans) contained in the endosperm of the seeds. Nevertheless, carob pod consists for the most part of pulp (90\%), which is rich in sugars [1] [4]-[6], but it also contains lots of polyphenols, especially highly condensed tannins 
(proanthocyanidins) [3] [7] [8], composed of flavan-3-ol groups and their galloyl esters [5] [9], gallic acid [8] [10], (+)-catechin, (-)-epicatechingallate, (-)-epigallocatechingallate and quercetin glycosides [11]. In 1984, Würsch et al. [4] studied polyphenols structure in carob pulp and found out that they are light brown granules whose size is 100 $500 \mu \mathrm{m}$. These granules are in the fiber fraction of pulp and can be extracted with polar solvents at high temperatures. Examined by electronic microscope, carob pulp was proved to contain tannin granules enclosed in parenchyma cells. Analysis by X-ray diffraction demonstrates that these granules do not have crystal structure.

Due to their chemical composition, carobs are used in industry, in food and in medicine [12]. Industrial use lies in gum production, taken from seeds after shuttering and separation, used as a thickening agent in many commercial food products as well as in textile industry [13]. Moreover, different human foods can be derived from the pulp such as sugar syrups or molasses, unroasted and roasted carob powder used as cocoa substitutes, or especially tannin rich preparations as anti-diarrheic products [7] [14]. Furthermore, carob pods have demonstrated interesting anti-cardiovascular and antioxidant properties, apparently related to their phenolic compounds content [3] [12] [15].

As Morocco is the fifth carob producer in the world after Spain, Italy, Portugal and Greece [16], plus the biological importance of some chemical compounds and their strong association with health benefits, an effort has been made to quantify total polyphenols, flavonoids and tannins in carob pulps of 12 wild and 8 domesticated trees from 15 different localities in Morocco, in order to evaluate differences between these two tree types.

\section{Materials and Methods}

\subsection{Chemicals}

Acetone $\left(\mathrm{C}_{3} \mathrm{H}_{6} \mathrm{O}\right) ; \mathrm{M}=58.08 \mathrm{~g} / \mathrm{mol}$; S.C. Chemical Company S.A., Iasi, Romania. Sodium carbonate $\mathrm{Na}_{2} \mathrm{CO}_{3} ; \mathrm{M}=105.99 \mathrm{~g} / \mathrm{mol}$; S.C. Chemical Company S.A., Iasi, Romania. Folin-Ciocalteu reagent; $1 \mathrm{~L}=1.24 \mathrm{~kg}$; Merck KGa A., Darmstadt, Germany. Gallic acid $(\mathrm{OH})_{3} \mathrm{C}_{6} \mathrm{H}_{2} \mathrm{COOH} \cdot \mathrm{H}_{2} \mathrm{O} ; \mathrm{M}=188.139 \mathrm{~g} / \mathrm{mol}$; Union Chimique Belge, S.A., Brussels, Belgium. Hexahydrated Aluminum Chloride $\mathrm{AlCl}_{3} \cdot 6 \mathrm{H}_{2} \mathrm{O} ; \mathrm{M}=241.43 \mathrm{~g} / \mathrm{mol}$; Chemical Company, Iasi, Romania. Solid Quercetin $\geq 95 \%$ (HPLC); $\mathrm{M}=302.24 \mathrm{~g} / \mathrm{mol}$; Sigma Aldrich, India. Ammonium iron (II) sulfate 99.7\%; $\left(\mathrm{NH}_{4}\right)_{2} \mathrm{Fe}\left(\mathrm{SO}_{4}\right)_{2} \cdot 6 \mathrm{H}_{2} \mathrm{O} ; \mathrm{M}=392.158$ g/mol; Chimopar S.A., Bucharest, Romania. n-Butan-1-ol $\mathrm{CH}_{3}\left(\mathrm{CH}_{2}\right)_{3} \mathrm{OH} ; 1 \mathrm{~L}=0.81 \mathrm{~kg}$; $\mathrm{M}=74.12 \mathrm{~g} / \mathrm{mol}$; Merck KGah, Darmstadt, Germany. Hydrochloric acid HCl 37\%; $1 \mathrm{~L}$ $=1.19 \mathrm{~kg} ; \mathrm{M}=36.46 \mathrm{~g} / \mathrm{mol}$; Lachner, Neratovice, Czech Republic.

\subsection{Plant Material}

Carob mature fruits have been collected from 12 wild trees and 8 domesticated ones from 15 different localities in Morocco. Collection has been carried out between July and September 2012. Fruits were stored in the dark at room temperature $\left(25^{\circ} \mathrm{C} \pm 2{ }^{\circ} \mathrm{C}\right)$. Origins, localities, numbers, latitudes, longitudes and altitudes may be seen in Table 1 . 
Table 1. Geographic coordinates (latitude and longitude) and altitudes of 20 carob trees in four regions from 15 Moroccan localities.

\begin{tabular}{|c|c|c|c|c|c|}
\hline Region & Locality & $\begin{array}{c}\text { Tree } \\
\text { number }\end{array}$ & Latitude & Longitude & $\begin{array}{c}\text { Altitude } \\
(\mathrm{m})\end{array}$ \\
\hline \multicolumn{6}{|c|}{ Wild trees } \\
\hline \multirow{8}{*}{$\begin{array}{c}\text { Western } \\
\text { Rif }\end{array}$} & Ghorghez (Zaitouna-Tetouan) & 1 & $35^{\circ} 32^{\prime} 45.48^{\prime \prime} \mathrm{N}$ & $5^{\circ} 23^{\prime} 08.62^{\prime \prime} \mathrm{W}$ & 204 \\
\hline & Zinat (Bni Hassane-Tetouan) & 2 & $35^{\circ} 25^{\prime} 13.22^{\prime \prime} \mathrm{N}$ & $5^{\circ} 23^{\prime} 23.54^{\prime \prime} \mathrm{W}$ & 330 \\
\hline & Isslan (Bni Hassane-Tetouan) & 3 & $35^{\circ} 16^{\prime} 57.66^{\prime \prime} \mathrm{N}$ & $5^{\circ} 16^{\prime} 33.56^{\prime \prime} \mathrm{W}$ & 876 \\
\hline & Belyounech (Fnidaq) & 4 & $35^{\circ} 54^{\prime} 15.70^{\prime \prime} \mathrm{N}$ & $5^{\circ} 23 ' 23.95^{\prime \prime} \mathrm{W}$ & 172 \\
\hline & Ain Beida 2 (Mokrissat-Ouezzane) & 5 & $34^{\circ} 58^{\prime} 52.17^{\prime \prime} \mathrm{N}$ & $5^{\circ} 29^{\prime} 42.16^{\prime \prime} \mathrm{W}$ & 178 \\
\hline & Ain Kalaa (Mokrissat-Ouezzane) & 6 & $34^{\circ} 55^{\prime} 55.21^{\prime \prime} \mathrm{N}$ & $5^{\circ} 21^{\prime} 16.55^{\prime \prime} \mathrm{W}$ & 643 \\
\hline & Ain Koub (Mokrissat-Ouezzane) & 7 & $34^{\circ} 57^{\prime} 08.68^{\prime \prime N}$ & $5^{\circ} 21^{\prime} 45.01^{\prime \prime} \mathrm{W}$ & 642 \\
\hline & Zoumi 2 (Mokrissat-Ouezzane) & 8 & $34^{\circ} 51^{\prime} 23.88^{\prime \prime} \mathrm{N}$ & $5^{\circ} 18^{\prime} 35.25^{\prime \prime} \mathrm{W}$ & 648 \\
\hline \multirow{2}{*}{$\begin{array}{c}\text { Eastern } \\
\text { Rif }\end{array}$} & Midar (Nador) & 9 & $34^{\circ} 58^{\prime} 20.56^{\prime \prime} \mathrm{N}$ & $3^{\circ} 37^{\prime} 38.80^{\prime \prime} \mathrm{W}$ & 1061 \\
\hline & Kassita (Nador) & 10 & $34^{\circ} 53^{\prime} 22.12^{\prime \prime} \mathrm{N}$ & $3^{\circ} 46^{\prime} 59.38^{\prime \prime} \mathrm{W}$ & 860 \\
\hline \multirow{3}{*}{$\begin{array}{c}\text { Western } \\
\text { Middle } \\
\text { Atlas }\end{array}$} & Guelmouss (Sidi Hassine-Khenifra) & 11 & $33^{\circ} 09^{\prime} 05.60^{\prime \prime} \mathrm{N}$ & $5^{\circ} 52^{\prime} 37.40^{\prime \prime} \mathrm{W}$ & 1250 \\
\hline & Ain Asserdoune (Beni Mellal) & 12 & $32^{\circ} 19^{\prime} 18.70^{\prime \prime} \mathrm{N}$ & $6^{\circ} 19^{\prime} 45.72^{\prime \prime} \mathrm{W}$ & 834 \\
\hline & \multicolumn{4}{|c|}{ Domesticated trees } & \\
\hline \multirow{5}{*}{$\begin{array}{c}\text { Western } \\
\text { Rif }\end{array}$} & M'hannech II (Tetouan) & 13 & $35^{\circ} 33^{\prime} 39.95^{\prime \prime} \mathrm{N}$ & $5^{\circ} 21^{\prime} 44.52^{\prime \prime} \mathrm{W}$ & 60 \\
\hline & Kitane (Zaitouna-Tetouan) & 14 & $35^{\circ} 32^{\prime} 15.50^{\prime \prime} \mathrm{N}$ & $5^{\circ} 20^{\prime} 20.57^{\prime \prime} \mathrm{W}$ & 126 \\
\hline & Oued Laou & 15 & $35^{\circ} 26^{\prime} 46.90^{\prime \prime} \mathrm{N}$ & $5^{\circ} 05^{\prime} 51.72^{\prime \prime} \mathrm{W}$ & 58 \\
\hline & Ain Beida 1(Mokrissat-Ouezzane) & 16 & $34^{\circ} 58^{\prime} 56.24^{\prime \prime} \mathrm{N}$ & $5^{\circ} 29^{\prime} 39.16^{\prime \prime} \mathrm{W}$ & 174 \\
\hline & Zoumi 1 (Mokrissat-Ouezzane) & 17 & $34^{\circ} 48^{\prime} 21.34^{\prime \prime} \mathrm{N}$ & $5^{\circ} 21^{\prime} 14.94^{\prime \prime} \mathrm{W}$ & 543 \\
\hline \multirow{3}{*}{$\begin{array}{c}\text { Eastern } \\
\text { Middle } \\
\text { Atlas }\end{array}$} & Moulay Idriss Zerhoun 1 & 18 & $34^{\circ} 03^{\prime} 33.97^{\prime \prime} \mathrm{N}$ & $5^{\circ} 31^{\prime} 52.70 " \mathrm{~W}$ & 482 \\
\hline & Moulay Idriss Zerhoun 2 & 19 & $34^{\circ} 03^{\prime} 35.47^{\prime \prime} \mathrm{N}$ & $5^{\circ} 32^{\prime} 05.36^{\prime \prime} \mathrm{W}$ & 470 \\
\hline & Moulay Idriss Zerhoun 3 & 20 & $34^{\circ} 03^{\prime} 27.87^{\prime \prime} \mathrm{N}$ & $5^{\circ} 31^{\prime} 55.70^{\prime \prime} \mathrm{W}$ & 466 \\
\hline
\end{tabular}

\subsection{Preparation of Carob Powder}

Fresh carob fruits have been dried during 2 weeks at $70^{\circ} \mathrm{C}$ until stabilization of dry weight. Dried fruits have been chopped, deseeded and crushed on a knife mill MICROTRON MB 500 (KINEMATICA) at 15,000 rpm. The resulted powder has been sifted on a stainless steel sieve Fisher Scientific LABOSI to obtain particles of average diameter less than $200 \mu \mathrm{m}$. The latter powder was used for extraction.

\subsection{Polyphenols Extraction}

$20 \mathrm{~g}$ of powder was macerated in $200 \mathrm{~mL}$ distillated water $6 \mathrm{~h}$ at $4^{\circ} \mathrm{C}$. Then, this mixture was centrifuged $15 \mathrm{~min}$ at $5000 \mathrm{rpm}$. The fresh residue was extracted with $70 \%$ acetone (ratio of extraction 1:5; w/v) with a magnetic stirrer (30 min; $350 \mathrm{rpm}$ ), then centrifuged $10 \mathrm{~min}$ at $5000 \mathrm{rpm}$. This extraction was repeated two times. The three supernatants were pooled and incubated at $4^{\circ} \mathrm{C}$ until analyses. 


\subsection{Total Polyphenols Content}

The total polyphenols content was determined by the Folin-Ciocalteu colorimetric method [17] [18], with some modifications. Carob pulp extract was diluted at 1:10 in distilled water and $0.6 \mathrm{~mL}$ was mixed with $5 \mathrm{~mL}$ distillated water and $3 \mathrm{~mL}$ Folin-Ciocalteu reagent $1 \mathrm{~N}$ diluted at 1:10. After 3 min waiting, $1 \mathrm{~mL}$ of sodium carbonate solution ( $10 \% \mathrm{Na}_{2} \mathrm{CO}_{3}$ in distillated water) was added. Finally, absorbance was measured by spectrophotometer UV-Vis (UV-1800; Shimadzu, Kyoto, Japan) at $725 \mathrm{~nm}$, after $2 \mathrm{~h}$ incubation at obscurity and $20^{\circ} \mathrm{C}$. Results were expressed as mg gallic acid equivalents by g of dry carob pulp powder (mg GAE/g).

\subsection{Total Flavonoids Content}

Flavonoids content was determined by the method described by Djeridane et al. [19] [20]. Carob pulp extract was diluted at $1: 5$ and $4.5 \mathrm{~mL}$ were mixed with $4.5 \mathrm{~mL}$ of aluminum chloride (2\%). Absorbance was measured by Spectrophotometer UV-Vis at 430 $\mathrm{nm}$, after $45 \mathrm{~min}$ incubation at obscurity and $20^{\circ} \mathrm{C}$. Results were expressed as mg quercetin equivalents by $g$ of dry carob pulp powder (mg QE/g).

\subsection{Condensed Tannins Content}

Condensed tannins content was determined by Butanol-HCl method [21] [22]. $0.5 \mathrm{~mL}$ of the extract was mixed with $3 \mathrm{~mL}$ of Butanol- $\mathrm{HCl}$ solution $(95: 5 \mathrm{v} / \mathrm{v})$ and $0.1 \mathrm{~mL}$ of ammonium iron (II) sulfate $(2 \%$ in $\mathrm{HCl} 2 \mathrm{~N})$. Absorbance was measured by Spectrophotometer UV-Vis at $550 \mathrm{~nm}$, after $1 \mathrm{~h}$ of incubation in boiling water bath protected from light. Results were expressed as mg proanthocyanidin equivalents by $\mathrm{g}$ of dry carob pulp powder (mg PE/g).

\subsection{Statistical Analysis}

All measurements were run in triplicates $(\mathrm{n}=3)$, and the values were averaged and given along with standard error $( \pm \mathrm{SE})$. Analyses were performed with Statistical 6; averages were compared by Duncan test and values beyond $\mathrm{p} \leq 0.05$ were considered to be significant.

\section{Results}

\subsection{Total Polyphenols Content}

For wild trees, $\mathrm{TPC}_{\mathrm{F}}$ ranged from 7.00 to $19.36 \mathrm{mg} \mathrm{GAE} / \mathrm{g}$, $\mathrm{TPC}_{\mathrm{D}}$ from 7.80 to $22.75 \mathrm{mg}$ $\mathrm{GAE} / \mathrm{g}$ and $\mathrm{TPC}_{\mathrm{P}}$ from 53.22 to $118.04 \mathrm{mg} \mathrm{GAE} / \mathrm{one}$ fresh pulp. Ghorghez powder showed the higher $\mathrm{TPC}_{\mathrm{F}}$ and $\mathrm{TPC}_{\mathrm{D}}$ (19.36 and $22.75 \mathrm{mg} \mathrm{GAE} / \mathrm{g}$ ), followed by Guelmouss (18.61 and 21.21) and Ain Asserdoune (17.25 and 19.41). Kassita powder had the lowest $\mathrm{TPC}_{\mathrm{F}}$ and $\mathrm{TPC}_{\mathrm{D}}(7.00$ and $7.80 \mathrm{mg} \mathrm{GAE} / \mathrm{g})$. The richest pulp in polyphenols belonged to the tree of Ain Beida 2 (118.04 mg GAE/one fresh pulp) followed by Zinat (109.36) and Ghorghez (107.83). The poorest pulp in polyphenols was from Guelmouss (53.22 mg GAE/one fresh pulp) Table 2. 
Table 2. Total polyphenols content (TPC) in mg gallic acid equivalents by $g$ of fresh powder, dry powder and by one carob fresh pulp for 12 wild and 8 domesticated carob trees.

\begin{tabular}{|c|c|c|c|c|}
\hline & Locality & $\begin{array}{c}\mathrm{TPC}_{\mathrm{F}} \\
(\mathrm{mg} \mathrm{GAE} / \mathrm{g})\end{array}$ & $\begin{array}{c}\mathrm{TPC}_{\mathrm{D}} \\
\text { (mg GAE/g) }\end{array}$ & $\begin{array}{c}\mathrm{TPC}_{\mathrm{P}} \\
\text { (mg GAE/one fresh pulp) }\end{array}$ \\
\hline \multicolumn{5}{|c|}{ Wild trees } \\
\hline 1 & Ghorghez (Zaitouna-Tetouan) & $19.36 \pm 0.06^{\mathrm{a}}$ & $22.75 \pm 0.07^{\mathrm{a}}$ & $107.83 \pm 0.33^{\mathrm{d}}$ \\
\hline 2 & Zinat (Bni Hassane-Tetouan) & $14.43 \pm 0.04^{\mathrm{f}}$ & $16.25 \pm 0.05^{\mathrm{f}}$ & $109.36 \pm 0.34^{\mathrm{d}}$ \\
\hline 3 & Isslan (Bni Hassane-Tetouan) & $15.50 \pm 0.04^{\mathrm{e}}$ & $18.65 \pm 0.04^{\mathrm{d}}$ & $65.28 \pm 0.16^{1}$ \\
\hline 4 & Belyounech (Fnidaq) & $12.47 \pm 0.04^{\mathrm{h}}$ & $14.39 \pm 0.05^{\mathrm{h}}$ & $108.64 \pm 0.38^{\mathrm{d}}$ \\
\hline 5 & Ain Beida 2 (Mokrissat-Ouezzane) & $9.29 \pm 0.09^{1}$ & $10.80 \pm 0.10^{\mathrm{k}}$ & $118.04 \pm 1.13^{\mathrm{c}}$ \\
\hline 6 & Ain Kalaa (Mokrissat-Ouezzane) & $7.55 \pm 0.02^{\mathrm{p}}$ & $8.54 \pm 0.02^{\circ}$ & $85.64 \pm 0.22^{\mathrm{i}}$ \\
\hline 7 & Ain Koub (Mokrissat-Ouezzane) & $8.58 \pm 0.12^{\mathrm{n}}$ & $10.07 \pm 0.13^{1}$ & $54.88 \pm 0.74^{\mathrm{n}}$ \\
\hline 8 & Zoumi 2 (Mokrissat-Ouezzane) & $13.91 \pm 0.07^{\mathrm{g}}$ & $15.90 \pm 0.07^{\mathrm{g}}$ & $103.04 \pm 0.48^{\mathrm{e}}$ \\
\hline 9 & Midar (Nador) & $8.53 \pm 0.18^{\mathrm{n}}$ & $10.02 \pm 0.20^{\mathrm{lm}}$ & $66.73 \pm 1.36^{1}$ \\
\hline 10 & Kassita (Nador) & $7.00 \pm 0.04^{\mathrm{r}}$ & $7.80 \pm 0.05^{p}$ & $73.21 \pm 0.48^{j}$ \\
\hline 11 & Guelmouss (Sidi Hassine-Khenifra) & $18.61 \pm 0.05^{\mathrm{b}}$ & $21.21 \pm 0.05^{\mathrm{b}}$ & $53.22 \pm 0.14^{\circ}$ \\
\hline 12 & Ain Asserdoune (Beni Mellal) & $17.25 \pm 0.10^{c}$ & $19.41 \pm 0.11^{\mathrm{c}}$ & $88.49 \pm 0.50^{\mathrm{h}}$ \\
\hline \multicolumn{5}{|c|}{ Domesticated trees } \\
\hline 13 & M'hannech II (Tetouan) & $6.97 \pm 0.02^{\mathrm{r}}$ & $8.43 \pm 0.02^{\circ}$ & $57.46 \pm 0.17^{\mathrm{m}}$ \\
\hline 14 & Kitane (Zaitouna-Tetouan) & $9.05 \pm 0.04^{\mathrm{m}}$ & $9.86 \pm 0.04^{\mathrm{m}}$ & $88.26 \pm 0.37^{\mathrm{h}}$ \\
\hline 15 & Oued Laou & $10.73 \pm 0.04^{j}$ & $11.99 \pm 0.05^{j}$ & $90.52 \pm 0.36^{\mathrm{g}}$ \\
\hline 16 & Ain Beida 1 (Mokrissat-Ouezzane) & $11.07 \pm 0.02^{\mathrm{i}}$ & $12.24 \pm 0.02^{\mathrm{i}}$ & $157.16 \pm 0.33^{\mathrm{b}}$ \\
\hline 17 & Zoumi 1 (Mokrissat-Ouezzane) & $16.04 \pm 0.04^{\mathrm{d}}$ & $18.06 \pm 0.04^{\mathrm{e}}$ & $183.31 \pm 0.44^{\mathrm{a}}$ \\
\hline 18 & Moulay Idriss Zerhoun 1 & $10.48 \pm 0.04^{\mathrm{k}}$ & $11.84 \pm 0.04^{j}$ & $74.09 \pm 0.27^{j}$ \\
\hline 19 & Moulay Idriss Zerhoun 2 & $8.00 \pm 0.03^{\circ}$ & $9.05 \pm 0.03^{\mathrm{n}}$ & $69.92 \pm 0.24^{\mathrm{k}}$ \\
\hline 20 & Moulay Idriss Zerhoun 3 & $8.94 \pm 0.04^{\mathrm{m}}$ & $10.19 \pm 0.04^{1}$ & $100.42 \pm 0.43^{\mathrm{f}}$ \\
\hline
\end{tabular}

TPC $_{\mathrm{F}}$ : Total Polyphenols Content in Fresh powder, $\mathrm{TPC}_{\mathrm{D}}$ : Total Polyphenols Content in Dry powder, TPC : Total Polyphenols Content in one fresh Pulp. The data represent Mean \pm SE of replicates $(n=3)$. Values in the same rows carrying different letters are significantly different between treatments and control by Duncan's multiple range tests at $\mathrm{p} \leq 0.05$.

For domesticated trees, $\mathrm{TPC}_{\mathrm{F}}$ ranged from 6.97 to $16.04 \mathrm{mg} \mathrm{GAE} / \mathrm{g}, \mathrm{TPC}_{\mathrm{D}}$ from 8.43 to $18.06 \mathrm{mg} \mathrm{GAE} / \mathrm{g}$ and $\mathrm{TPC}_{\mathrm{P}}$ from 57.46 to $183.31 \mathrm{mg}$ GAE/one fresh pulp. Powder from domesticated tree of Zoumi 1 was the richest in polyphenols (16.04 and $18.06 \mathrm{mg}$ GAE/g for $\mathrm{TPC}_{\mathrm{F}}$ and $\mathrm{TPC}_{\mathrm{D}}$ ), followed by Ain Beida 1 (11.07 and 12.24) and Oued Laou (10.73 and 11.99). Moulay Idriss Zerhoun 2 powder showed the lowest $\mathrm{TPC}_{\mathrm{F}}$ and $\mathrm{TPC}_{\mathrm{D}}$ (8.00 and $9.05 \mathrm{mg} \mathrm{GAE} / \mathrm{g}$ ). The richest pulp in polyphenols belonged to the domesticated tree of Zoumi 1 (183.31 mg GAE/one fresh pulp), followed by Ain Beida 1 (157.16) and Moulay Idriss Zerhoun 3 (100.42). The poorest pulp in polyphenols was from M'hannech II with $57.46 \mathrm{mg}$ GAE/one fresh pulp Table 2. 


\subsection{Total Flavonoids Content}

For wild trees, $\mathrm{TFC}_{\mathrm{F}}$ ranged from 0.19 to $0.87 \mathrm{mg} \mathrm{QE} / \mathrm{g}, \mathrm{TFC}_{\mathrm{D}}$ from 0.21 to $1.02 \mathrm{mg}$ $\mathrm{QE} / \mathrm{g}$ and $\mathrm{TFC}_{\mathrm{P}}$ from 1.41 to $4.83 \mathrm{mg} \mathrm{QE} / \mathrm{g}$. Powder from Ghorghez tree showed the highest $\mathrm{TFC}_{\mathrm{F}}$ and $\mathrm{TFC}_{\mathrm{D}}(0.87$ and $1.02 \mathrm{mg} \mathrm{QE} / \mathrm{g}$, respectively), followed by powders from Guelmouss tree (0.67 and 0.77), and Zoumi 2 tree (0.49 and 0.55). The lowest $\mathrm{TFC}_{\mathrm{F}}$ and $\mathrm{TFC}_{\mathrm{D}}$ were observed in the case of powder from Ain Kalaa tree (0.19 and 0.21 $\mathrm{mg} \mathrm{QE} / \mathrm{g})$. The richest pulp in flavonoids was from Ghorghez tree with $4.83 \mathrm{mg} \mathrm{QE} / \mathrm{one}$ fresh pulp, followed by Belyounech (3.96) and Zoumi 2 (3.60) trees. The poorest pulp in flavonoids was from Isslan tree with $1.41 \mathrm{mg} \mathrm{QE} /$ one fresh pulp Table 3.

Table 3. Total flavonoids content (TFC) in mg quercetin equivalents by $g$ of fresh powder, dry powder and one fresh pulp for 12 wild and 8 domesticated carob trees in Morocco.

\begin{tabular}{|c|c|c|c|c|}
\hline & Locality & $\begin{array}{c}\mathrm{TFC}_{\mathrm{F}} \\
(\mathrm{mg} \mathrm{QE} / \mathrm{g})\end{array}$ & $\begin{array}{c}\mathrm{TFC}_{\mathrm{D}} \\
(\mathrm{mg} \mathrm{QE} / \mathrm{g})\end{array}$ & $\begin{array}{c}\mathrm{TFC}_{\mathrm{P}} \\
\text { (mg QE/one fresh pulp) }\end{array}$ \\
\hline \multicolumn{5}{|c|}{ Wild trees } \\
\hline 1 & Ghorghez (Zaitouna-Tetouan) & $0.87 \pm 0.001^{\mathrm{a}}$ & $1.02 \pm 0.0006^{\mathrm{a}}$ & $4.83 \pm 0.003^{\mathrm{b}}$ \\
\hline 2 & Zinat (Bni Hassane-Tetouan) & $0.36 \pm 0.001^{\mathrm{f}}$ & $0.41 \pm 0.001^{\mathrm{g}}$ & $2.76 \pm 0.008^{\mathrm{h}}$ \\
\hline 3 & Isslan (Bni Hassane-Tetouan) & $0.34 \pm 0.01^{\mathrm{ghi}}$ & $0.40 \pm 0.01^{\mathrm{gh}}$ & $1.41 \pm 0.04^{\mathrm{n}}$ \\
\hline 4 & Belyounech (Fnidaq) & $0.46 \pm 0.003^{\mathrm{e}}$ & $0.52 \pm 0.004^{\mathrm{e}}$ & $3.96 \pm 0.03^{\mathrm{e}}$ \\
\hline 5 & Ain Beida 2 (Mokrissat-Ouezzane) & $0.25 \pm 0.003^{\mathrm{jk}}$ & $0.28 \pm 0.004^{j}$ & $3.12 \pm 0.04^{\mathrm{g}}$ \\
\hline 6 & Ain Kalaa (Mokrissat-Ouezzane) & $0.19 \pm 0.009^{\mathrm{m}}$ & $0.21 \pm 0.01^{\mathrm{m}}$ & $2.11 \pm 0.11^{j}$ \\
\hline 7 & Ain Koub (Mokrissat-Ouezzane) & $0.26 \pm 0.003^{j}$ & $0.30 \pm 0.004^{j}$ & $1.64 \pm 0.02^{1 \mathrm{~m}}$ \\
\hline 8 & Zoumi 2 (Mokrissat-Ouezzane) & $0.49 \pm 0.005^{\mathrm{d}}$ & $0.55 \pm 0.006^{\mathrm{d}}$ & $3.60 \pm 0.04^{\mathrm{f}}$ \\
\hline 9 & Midar (Nador) & $0.20 \pm 0.006^{\mathrm{lm}}$ & $0.23 \pm 0.006^{1}$ & $1.56 \pm 0.04^{\mathrm{mn}}$ \\
\hline 10 & Kassita (Nador) & $0.23 \pm 0.011^{\mathrm{k}}$ & $0.26 \pm 0.01^{\mathrm{k}}$ & $2.45 \pm 0.11^{\mathrm{i}}$ \\
\hline 11 & Guelmouss (Sidi Hassine-Khenifra) & $0.67 \pm 0.002^{\mathrm{b}}$ & $0.77 \pm 0.002^{\mathrm{b}}$ & $1.93 \pm 0.006^{\mathrm{k}}$ \\
\hline 12 & Ain Asserdoune (Beni Mellal) & $0.35 \pm 0.002^{\mathrm{fg}}$ & $0.39 \pm 0.002^{\mathrm{gh}}$ & $1.79 \pm 0.008^{\mathrm{kl}}$ \\
\hline \multicolumn{5}{|c|}{ Domesticated trees } \\
\hline 13 & M'hannech II (Tetouan) & $0.48 \pm 0.009^{\mathrm{d}}$ & $0.57 \pm 0.01^{\mathrm{d}}$ & $3.91 \pm 0.08^{\mathrm{e}}$ \\
\hline 14 & Kitane (Zaitouna-Tetouan) & $0.45 \pm 0.001^{\mathrm{e}}$ & $0.48 \pm 0.001^{\mathrm{f}}$ & $4,35 \pm 0.01^{\mathrm{d}}$ \\
\hline 15 & Oued Laou & $0.21 \pm 0.001^{1}$ & $0.23 \pm 0.001^{1}$ & $1.76 \pm 0.008^{\mathrm{kl}}$ \\
\hline 16 & Ain Beida 1(Mokrissat-Ouezzane) & $0.33 \pm 0.01^{\mathrm{hi}}$ & $0.36 \pm 0.01^{\mathrm{i}}$ & $4.65 \pm 0.13^{\mathrm{c}}$ \\
\hline 17 & Zoumi 1 (Mokrissat-Ouezzane) & $0.65 \pm 0.01^{\mathrm{c}}$ & $0.73 \pm 0.01^{\mathrm{c}}$ & $7.46 \pm 0.12^{\mathrm{a}}$ \\
\hline 18 & Moulay Idriss Zerhoun 1 & $0.34 \pm 0.006^{\mathrm{gh}}$ & $0.36 \pm 0.004^{\mathrm{i}}$ & $2.41 \pm 0.04^{\mathrm{i}}$ \\
\hline 19 & Moulay Idriss Zerhoun 2 & $0.19 \pm 0.003^{\mathrm{m}}$ & $0.21 \pm 0.003^{\mathrm{m}}$ & $1.62 \pm 0.02^{1 \mathrm{~m}}$ \\
\hline 20 & Moulay Idriss Zerhoun 3 & $0.32 \pm 0.003^{\mathrm{i}}$ & $0.38 \pm 0.01^{\mathrm{h}}$ & $3.59 \pm 0.04^{\mathrm{f}}$ \\
\hline
\end{tabular}

$\mathrm{TFC}_{\mathrm{F}}$ : Total Flavonoids Content in Fresh powder, $\mathrm{TFC}_{\mathrm{D}}$ : Total Flavonoids Content in Dry powder, TFC $\mathrm{p}$ : Total Flavonoids Content in one fresh Pulp. The data represent Mean \pm SE of replicates $(n=3)$. Values in the same rows carrying different letters are significantly different between treatments and control by Duncan's multiple range tests at $p$ $\leq 0.05$. 
For domesticated trees, $\mathrm{TFC}_{\mathrm{F}}$ ranged from 0.19 to $0.65 \mathrm{mg} \mathrm{QE} / \mathrm{g}, \mathrm{TFC}_{\mathrm{D}}$ from 0.21 to $0.73 \mathrm{mg} \mathrm{QE} / \mathrm{g}$ and $\mathrm{TFC}_{\mathrm{P}}$ from 1.62 to $7.46 \mathrm{mg} \mathrm{QE} / \mathrm{g}$. Fresh and dry powders from Zou$\mathrm{mi} 1$ tree were the richest in flavonoids ( 0.65 and $0.73 \mathrm{mg} \mathrm{QE} / \mathrm{g}$, respectively), followed by M'hannech II tree (0.48 and 0.57$)$ and Kitane tree $(0.45$ and 0.48$)$. Fresh and dry powders of Moulay Idriss Zerhoun 2 tree were the poorest in flavonoids with a $\mathrm{TFC}_{\mathrm{F}}$ and $\mathrm{a} \mathrm{TFC}_{\mathrm{D}}$ of 0.19 and $0.21 \mathrm{mg} \mathrm{QE} / \mathrm{g}$. Pulp from Zoumi 1 tree showed the highest $\mathrm{TFC}_{\mathrm{P}}$ (7.46 mg QE/one fresh pulp), followed by Ain Beida 1(4.65) and Kitane (4.35) trees. The poorest pulp in flavonoids was from Moulay Idriss Zerhoun 2 tree with a $\mathrm{TFC}_{\mathrm{P}}$ of $1.62 \mathrm{mg} \mathrm{QE} /$ one fresh pulp Table 3.

\subsection{Condensed Tannins Content}

For wild trees, $\mathrm{CTC}_{\mathrm{F}}$ ranged from 0.30 to $0.85 \mathrm{mg} \mathrm{PE} / \mathrm{g}, \mathrm{CTC}_{\mathrm{D}}$ from 0.35 to $1.02 \mathrm{mg}$ $\mathrm{PE} / \mathrm{g}$ and $\mathrm{CTC}_{\mathrm{P}}$ from 1.47 to $7.36 \mathrm{mg} \mathrm{PE} /$ one fresh pulp. The highest $\mathrm{CTC}_{\mathrm{F}}$ and $\mathrm{CTC}_{\mathrm{D}}$ corresponded to the powder of Isslan tree ( 0.85 and $1.02 \mathrm{mg} \mathrm{PE} / \mathrm{g}$, respectively), followed by the powders from Ghorghez (0.72 and 0.84) and Midar (0.68 and 0.80) trees. The lowest $\mathrm{CTC}_{\mathrm{F}}$ and $\mathrm{CTC}_{\mathrm{D}}$ corresponded to the powder of Ain Koub (0.30 and 0.35 $\mathrm{mg} \mathrm{PE} / \mathrm{g}$ ). The richest pulp in condensed tannins belonged to Ain Kalaa tree (7.36 mg $\mathrm{PE} /$ one fresh pulp), followed by Ain Beida 2 (6.61) and Midar (5.35) trees. The poorest pulp in condensed tannins belonged to Guelmouss tree with $1.47 \mathrm{mg}$ PE/one fresh pulp Table 4.

For domesticated trees, $\mathrm{CTC}_{\mathrm{F}}$ ranged from 0.22 to $0.59 \mathrm{mg} \mathrm{PE} / \mathrm{g}, \mathrm{CTC}_{\mathrm{D}}$ from 0.24 to $0.68 \mathrm{mg} \mathrm{PE} / \mathrm{g}$ and $\mathrm{CTC}_{\mathrm{P}}$ from 1.85 to $6.66 \mathrm{mg}$ PE/one fresh pulp. Powder from Moulay Idriss Zerhoun 3 tree showed the highest $\mathrm{CTC}_{\mathrm{F}}$ and $\mathrm{CTC}_{\mathrm{D}}(0.59$ and $0.68 \mathrm{mg} \mathrm{PE} / \mathrm{g}$, respectively), followed by the powders from Zoumi 1 (0.48 and 0.54) and Kitane (0.47 and 0.51$)$ trees. Powder from Oued Laou tree showed the lowest $\mathrm{CTC}_{\mathrm{F}}$ and $\mathrm{CTC}_{\mathrm{D}}(0.22$ and $0.24 \mathrm{mg} \mathrm{PE} / \mathrm{g}$ ). The richest pulp in condensed tannins was from Moulay Idriss Zerhoun 3 tree with $6.66 \mathrm{mg}$ PE/one fresh pulp, followed by Ain Beida 1 (6.37) and Zoumi 1 (5.47) trees. The poorest pulp in condensed tannins was from Oued Laou tree with $1.85 \mathrm{mg}$ PE/one fresh pulp Table 4.

\section{Discussion}

The present study highlights differences in polyphenols contents among powders and pulps from wild and domesticated trees of Ceratonia siliqua L.

Thereby, carob dry powders from wild trees show total polyphenols, flavonoids and condensed tannins contents reaching $22.75 \mathrm{mg}$ GAE/g, $1.02 \mathrm{mg} \mathrm{QE} / \mathrm{g}$ and $1.02 \mathrm{mg}$ $\mathrm{PE} / \mathrm{g}$, respectively. Also, pulps from wild trees show total polyphenols, total flavonoids and condensed tannins contents by one fresh carob pulp reaching 118.04 mg GAE, 4.83 mg QE and 7.36 mg PE, respectively, while domesticated trees show lower contents for powders. Thus, total polyphenols, flavonoids and condensed tannins contents reach $18.06 \mathrm{mg} \mathrm{GAE} / \mathrm{g}, 0.73 \mathrm{mg} \mathrm{QE} / \mathrm{g}$ and $0.68 \mathrm{mg} \mathrm{PE} / \mathrm{g}$, respectively. For one fresh carob pulp, they reach $183.31 \mathrm{mg}$ GAE, $7.46 \mathrm{mg} \mathrm{QE}$ and $6.66 \mathrm{mg} \mathrm{PE}$, respectively. Indeed, Marakis et al. [23] found that wild carob populations are richer in tannins than domesticated ones. 
Table 4. Condensed tannins content (CTC) in $\mathrm{mg}$ proanthocyanidin equivalents by $\mathrm{g}$ of fresh powder, dry powder and one fresh pulp for 12 wild and 8 domesticated carob trees in Morocco.

\begin{tabular}{|c|c|c|c|c|}
\hline & Locality & $\begin{array}{c}\mathrm{CTC}_{\mathrm{F}} \\
(\mathrm{mg} \mathrm{PE} / \mathrm{g})\end{array}$ & $\begin{array}{c}\mathrm{CTC}_{\mathrm{D}} \\
(\mathrm{mg} \mathrm{PE} / \mathrm{g})\end{array}$ & $\begin{array}{c}\mathrm{CTC}_{\mathrm{P}} \\
\text { (mg PE/one fresh pulp) }\end{array}$ \\
\hline \multicolumn{5}{|c|}{ Wild Trees } \\
\hline 1 & Ghorghez (Zaitouna-Tetouan) & $0.72 \pm 0.007^{\mathrm{b}}$ & $0.84 \pm 0.01^{\mathrm{b}}$ & $4.00 \pm 0.04^{\mathrm{g}}$ \\
\hline 2 & Zinat (Bni Hassane-Tetouan) & $0.54 \pm 0.003^{\mathrm{f}}$ & $0.61 \pm 0.003^{g}$ & $4.13 \pm 0.02^{\mathrm{g}}$ \\
\hline 3 & Isslan (Bni Hassane-Tetouan) & $0.85 \pm 0.008^{\mathrm{a}}$ & $1.02 \pm 0.01^{\mathrm{a}}$ & $3.57 \pm 0.03^{\mathrm{h}}$ \\
\hline 4 & Belyounech (Fnidaq) & $0.54 \pm 0.006^{\mathrm{f}}$ & $0.62 \pm 0.01^{\mathrm{fg}}$ & $4.70 \pm 0.05^{\mathrm{f}}$ \\
\hline 5 & Ain Beida 2 (Mokrissat-Ouezzane) & $0.52 \pm 0.001^{\mathrm{g}}$ & $0.60 \pm 0.001^{\mathrm{g}}$ & $6.61 \pm 0.02^{\mathrm{b}}$ \\
\hline 6 & Ain Kalaa (Mokrissat-Ouezzane) & $0,65 \pm 0,006^{\mathrm{d}}$ & $0.73 \pm 0.01^{\mathrm{d}}$ & $7.36 \pm 0.07^{\mathrm{a}}$ \\
\hline 7 & Ain Koub (Mokrissat-Ouezzane) & $0.30 \pm 0.001^{\mathrm{k}}$ & $0.35 \pm 0.001^{\mathrm{m}}$ & $1.90 \pm 0.009^{1}$ \\
\hline 8 & Zoumi 2 (Mokrissat-Ouezzane) & $0.56 \pm 0.02^{\mathrm{f}}$ & $0.63 \pm 0.02^{\mathrm{f}}$ & $4.11 \pm 0.11^{\mathrm{g}}$ \\
\hline 9 & Midar (Nador) & $0.68 \pm 0.004^{c}$ & $0.80 \pm 0.005^{\mathrm{c}}$ & $5.35 \pm 0.03^{\mathrm{d}}$ \\
\hline 10 & Kassita (Nador) & $0.47 \pm 0.002^{\mathrm{h}}$ & $0.52 \pm 0.002^{\mathrm{ij}}$ & $4.92 \pm 0.02^{\mathrm{e}}$ \\
\hline 11 & Guelmouss (Sidi Hassine-Khenifra) & $0.51 \pm 0.004^{\mathrm{g}}$ & $0.58 \pm 0.005^{\mathrm{h}}$ & $1.47 \pm 0.01^{\mathrm{m}}$ \\
\hline 12 & Ain Asserdoune (Beni Mellal) & $0.37 \pm 0.003^{j}$ & $0.42 \pm 0.003^{1}$ & $1.91 \pm 0.01^{1}$ \\
\hline \multicolumn{5}{|c|}{ Domesticated trees } \\
\hline 13 & M'hannech II (Tetouan) & $0.25 \pm 0.003^{1}$ & $0.31 \pm 0.003^{\mathrm{n}}$ & $2.09 \pm 0.02^{\mathrm{k}}$ \\
\hline 14 & Kitane (Zaitouna-Tetouan) & $0.47 \pm 0.007^{\mathrm{h}}$ & $0.51 \pm 0.01^{\mathrm{jk}}$ & $4.58 \pm 0.07^{\mathrm{f}}$ \\
\hline 15 & Oued Laou & $0.22 \pm 0.002^{\mathrm{m}}$ & $0.24 \pm 0.003^{\circ}$ & $1.85 \pm 0.02^{1}$ \\
\hline 16 & Ain Beida 1 (Mokrissat-Ouezzane) & $0.45 \pm 0.01^{\mathrm{i}}$ & $0.50 \pm 0.01^{\mathrm{k}}$ & $6.37 \pm 0.13^{c}$ \\
\hline 17 & Zoumi 1 (Mokrissat-Ouezzane) & $0.48 \pm 0.001^{\mathrm{h}}$ & $0.54 \pm 0.001^{\mathrm{i}}$ & $5.47 \pm 0.006^{\mathrm{d}}$ \\
\hline 18 & Moulay Idriss Zerhoun 1 & $0.37 \pm 0.002^{j}$ & $0.41 \pm 0.002^{1}$ & $4.09 \pm 0.01^{\mathrm{gh}}$ \\
\hline 19 & Moulay Idriss Zerhoun 2 & $0.37 \pm 0.001^{j}$ & $0.42 \pm 0.001^{1}$ & $2.60 \pm 0.01^{j}$ \\
\hline 20 & Moulay Idriss Zerhoun 3 & $0.59 \pm 0.006^{\mathrm{e}}$ & $0.68 \pm 0.01^{\mathrm{e}}$ & $6.66 \pm 0.07^{\mathrm{b}}$ \\
\hline
\end{tabular}

$\mathrm{CTC}_{\mathrm{F}}$ : Condensed Tannins Content in Fresh powder, $\mathrm{CTC}_{\mathrm{D}}$ : Condensed Tannins Content in Dry powder, CTC Condensed Tannins Content in one fresh Pulp. The data represent Mean \pm SE of replicates $(n=3)$. Values in the same rows carrying different letters are significantly different between treatments and control by Duncan's multiple range tests at $\mathrm{p} \leq 0.05$.

Furthermore, we notice variations in polyphenols contents among wild and/or domesticated trees from the same locality. This is the case for Bni Hassane (trees 2 and 3), Mokrissat (wild trees 5, 6 and 7, domesticated trees 16 and 17), Nador (trees 9 and 10) and Moulay Idriss Zerhoun (trees 18, 19 and 20). Within a same location, altitude can change: for example, trees 2 and 3 from Bni Hassane grow at 330 and $876 \mathrm{~m}$. This implies different environmental conditions (climate, soil...), which could influence the content of polyphenols [23]. On the other side, trees 18, 19 and 20 have approximate altitudes but different polyphenols contents, which may be explained by the age of tree, its physiological condition and other genetic reasons [23]. 
Our results are in the interval of results of other studies on carob tree. Difference depends on genetic, geographical, environmental, physiological and cultural conditions, sample preparations, extraction protocol and method of analysis.

Actually, hermaphrodite cultivars appeared richer than female in total polyphenols content of carob pulp (18.0 vs. $41.3 \mathrm{mg} \mathrm{GAE} / \mathrm{g}$ ), in flavonoids and condensed tannins, especially (+)-catechin (10.3 vs. $5.5 \mathrm{mg} / \mathrm{g}$ ) and gallic acid (1.8 vs. $1.1 \mathrm{mg}$ ) [24].

It was also found that the high growth activity in May is expressed both by higher photosynthetic rates and an increase in polyphenols, compared to June and October [25].

Benchikh et al. [26] have also compared pulps from one carob wild tree and two cultivated ones, in unripe stage, mid-ripe stage and ripe stage and observed that the total phenolic content and total flavonoids decreased with ripening. In addition, Ouzounidou et al. [25] observed that total polyphenols content gradually decreased with ripening.

Small pieces of pods $(0.5-1.0 \mathrm{~cm})$ eluted with water $(1: 4)$ using peristaltic pump, carob pods reduced to fine powder and mixed with water at a ratio (1:4) during $2 \mathrm{~h}$ at $45^{\circ} \mathrm{C}$ and particle size of $0.5-1.0 \mathrm{~cm}$ prepared as the previous powder were compared; the first resulted eluant and the two latter extracts were centrifuged at $3000 \mathrm{rpm}$ and $0^{\circ} \mathrm{C}$ for $30 \mathrm{~min}$; resulted extracts contained $0.06,0.11$ and $0.07 \mathrm{~g}$ TAE/ $100 \mathrm{~mL}$ of extract [27]. Likewise, two types of carob juice were tested, $0.5-1.0 \mathrm{~cm}$ and fine particle size; both particles were suspended in water and stirred at $43^{\circ} \mathrm{C}$ for $160 \mathrm{~min}$. Low differences were observed for total polyphenols content $(19.8 \pm 1.2 \mathrm{mg}$ vs.20.3 $\pm 1.4 \mathrm{mg} \mathrm{GAE} / \mathrm{g}$ of dry matter), total tannins content ( $4.3 \pm 0.2$ vs. $4.5 \pm 0.3 \mathrm{mg} \mathrm{CE} / \mathrm{g}$ of dried extract) and total flavonoids content ( $1.2 \pm 0.1$ vs. $1.5 \pm 0.1 \mathrm{mg} \mathrm{CE} / \mathrm{g}$ of dried extract) [28].

Optimization of yield can be accomplished by applying and controlling parameters of some processes like roasting. Kibbled carob was roasted at $135^{\circ} \mathrm{C}, 150^{\circ} \mathrm{C}$ and $165^{\circ} \mathrm{C}$ during $0,5,10,15,20,30,45,60,75$ and $90 \mathrm{~min}$. Roasted samples were then ground, sieved and stored at $4^{\circ} \mathrm{C}$ till extraction and analysis. Total phenolic content of nonroasted kibbled carob was $0.570 \mathrm{~g} / 100 \mathrm{~g}$ of dry matter and increased up to $0.865,0.986$ and $1.131 \mathrm{~g} / 100 \mathrm{~g}$ during the roasting process at $135^{\circ} \mathrm{C}, 150^{\circ} \mathrm{C}$ and $165^{\circ} \mathrm{C}$, respectively. Total polyphenols content was almost stable in the initial stage and gradually increased to a maximum level up to $75 \mathrm{~min}$ [29]. It was also found that the most acceptable roasted carob powder was obtained by roasting kibbled carob at $150^{\circ} \mathrm{C}$ for $60 \mathrm{~min}$ [30]. Beside, pulps can be frozen or lyophilized before extraction [31] or defatted [32], for example by hexane in a Soxhlet apparatus to remove lipids [24] [33] [34].

Different methods for polyphenols extraction are reported in literature including conventional methods using solvents, ultrasound extraction [35] and supercritical extraction [35] [36].

Kumazawa et al. [3] followed by [20] extracted carob pods, crushed and dried, during $12 \mathrm{~h}$ in cold water $\left(3^{\circ} \mathrm{C}\right)$. This operation, repeated two times, eliminated monosaccharides. Also, polyphenols extraction from carob pods has been performed with water at room temperature [35] [37] [38]. Also, it was demonstrated that extraction time (0.5, 1 , 
3, 5, 7 and $9 \mathrm{~h}$ ) had no effect on the quantity of extracted phenolic compounds at a ratio of 1:10 (w/v); but increasing the ratios carob pulp/water produced extracts richer in soluble polyphenolic compounds [38]. Phenol compounds have often been extracted from carob pod with boiling water [3] [39]. In a study applied in the industrial scale, 3 $\mathrm{kg}$ of carob pods, from trees in Turkey, was mixed with $17 \mathrm{~L}$ of water in a tank of $25 \mathrm{~L}$, equipped with heating/cooling system with circulation water by pumping. Three temperatures were tested: $20^{\circ} \mathrm{C}, 50^{\circ} \mathrm{C}$ and $85^{\circ} \mathrm{C}$. It was found that increasing the extraction temperature resulted in higher amounts of total polyphenols content [40].

Pod powder has been extracted by different solvent systems: $80 \%$ ethanol [41], pure ethanol [34] [42], 50\% acetone [43], $80 \%$ and $70 \%$ acetone [8] [35], $80 \%$ acetone [41], water:methanol:acetone (10:60:30) [44], 70\% methanol [8] [20], 80\% methanol [32] and pure methanol [24]. Pure acetone was inefficient for extraction of polyphenols: $100 \%$ acetone extracted $2.0 \mathrm{mg}$ of total polyphenols, $0.8 \mathrm{mg}$ of proanthocyanidins and $0.3 \mathrm{mg}$ ellagitannins/g of dried powder while 70\% acetone extracted 19.5, 2.9 and $0.46 \mathrm{mg}$. Furthermore, $70 \%$ acetone was more efficient in recovering tannins than was $70 \%$ methanol [8].

Benchikh and Louailèche [45] have first extracted fresh carob pods powder with water, $60 \%$ ethanol, $60 \%$ methanol and $60 \%$ acetone, using bath shaker. Different solvent concentrations $(40,60,80$ and $100 \%)$, ratios $(15: 10,25: 10,50: 10$ and $75 \mathrm{mg}: 10 \mathrm{~mL}$ ), extraction times $(60,90$ and $120 \mathrm{~min})$ and temperatures $\left(25^{\circ} \mathrm{C}, 50^{\circ} \mathrm{C}, 70^{\circ} \mathrm{C}\right.$ and $90^{\circ} \mathrm{C}$ ) were tested. Acetone $60 \%$ extract had the highest phenolic and flavonoids contents, followed by methanol $60 \%$, ethanol $60 \%$ and water extracts. Phenolic and flavonoids contents increased with the increasing proportion of acetone up to $70 \%$. The lowest phenolic contents were obtained with $100 \%$ acetone. The best phenolic and flavonoids contents were obtained with a ratio of $25 \mathrm{mg}: 10 \mathrm{~mL}$. Extraction time had significant effect on total phenolic and flavonoids content that increase from 60 to $90 \mathrm{~min}$. After 90 min, values decreased significantly. The best extraction of phenolic and flavonoids compounds was obtained at $90^{\circ} \mathrm{C}$.

In another study, water, ethanol, acetone and ethyl acetate were evaluated. Maximum quantities of polyphenols were obtained by $10 \%$ aqueous ethanol and maximum quantities of proanthocyanidins were obtained with $70 \%$ aqueous acetone [46].

A series of non toxic solvent systems, composed of water/ethanol, acidified and non acidified with either acetic or citric acid, were tested for their efficiency in extracting polyphenols from dried and ground carob kibbles. It was found that $30 \%$ ethanol was the best solvent system, providing extracts with high total polyphenolic content $(9.32 \pm$ $0.78 \mathrm{mg} \mathrm{GAE} / \mathrm{g}$ of dry powder) and high antioxidant activity. The highest yield of total polyphenols was achieved at $60^{\circ} \mathrm{C}[47]$.

In addition, carob kibbles (by-product of carob been gum production) from Portugal were submitted to an aqueous extraction to extract sugars, and supercritical fluid extraction was applied to the solid residue of that aqueous extraction, by using compressed carbon dioxide as the solvent and $80 \%$ ethanol as a co-solvent. Pressure and temperature were studied in the ranges $15-22 \mathrm{MPa}$ and $40^{\circ} \mathrm{C}-70^{\circ} \mathrm{C}$, respectively. Par- 
ticle diameter and co-solvent percentage are in ranges of $0.27-1.07 \mathrm{~mm}$ and $0 \%$ $12.4 \%$, respectively, as well as the flow rate of supercritical $\mathrm{CO}_{2}$ between 0.28 and 0.85 $\mathrm{kg} / \mathrm{h}$. The best results were found at $22 \mathrm{MPa}, 40^{\circ} \mathrm{C}, 0.27 \mathrm{~mm}$ particle size, about $12.4 \%$ of co-solvent and a flow rate of $0.29 \mathrm{~kg} / \mathrm{h}[36]$.

In the present study water was used as solvent system for polyphenols extraction, followed by acetone. It was proved that it attacks bonds established between polyphenolic structures and other macromolecules like proteins and lipids. Furthermore, reports about carob pod tannins have shown that they had a low solubility in solvents like methanol and ethanol. Actually, carob pod tannins are strongly polymerized with molecular weight attending 32,000 g/mol and have non-porous granular form [5] [7].

Methods of analysis can also explain the variation of contents. In this work, the condensed tannins content have been determined the proanthocyanidin assay (butanol$\mathrm{HCl}$ method). There is also the vanillin assay (vanillin- $\mathrm{H}_{2} \mathrm{SO}_{4}$ method) that provides the quantity of flavanols including catechins and proanthocyanidins [38]. The proanthocyanidin assay provides the degree of polymerization of proanthocyanidins, with a very specific reaction based on conversion to anthocyanidins by means of auto-oxidation following acid-catalyzed cleavage of the interflavonoid bonds [22]. Therefore, the ratio obtained by the vanillin assay divided by that obtained by the proanthocyanidin assay provides a rough estimate of the degree of polymerization of flavanols. Thereby, in the study carried out by Kumazawa et al. [3], the values determined by the vanillin assay and the proanthocyanidin assay were $4.37 \pm 0.1$ and $1.36 \pm 0.01 \mathrm{~g} / 100 \mathrm{~g}$ of carob pod crude polyphenols, respectively, thus indicating that the degree of polymerization of flavanols was $31.1 \%$ (1.36/4.37). Tannins content can also be determined with the gravimetric method using cupper acetate as an agent of association with phenol compounds [39]. Moreover, contrary to our results, Gaouar-Borsali [20] obtained more flavonoids than tannins.

\section{Conclusions}

In the present study, pods from Moroccan carob were found to have obvious variability of polyphenols content. Indeed, the twenty studied trees showed great variability in total polyphenols, flavonoids and condensed tannins contents.

Generally, it was found that pods powders from wild trees are richer in polyphenols than those from domesticated trees. Nevertheless, the second one has sometimes a tendency to reach the content of the first one. In addition, polyphenols content in the fresh pulp depends on its size and weight.

Also, pods from trees in the same region showed variable contents in polyphenols, flavonoids and condensed tannins.

This report is the one among others researches which proves that carob pulp (kibbled pod), especially from Morocco, is a rich source of polyphenols, shown to be natural bioactive compounds with several benefits. Also, it offers a tool for socio-economic development of local populations as an implement to some government institutions interested by protecting, valorizing genetic resources and developing the regional infor- 
mation system for the management of biodiversity. Moreover, the high pulp content of polyphenols found may encourage people to consume carob deseeded fruits.

\section{Acknowledgements}

We thank the Francophone University Agency (FUA) which financed this research in the form of a Research Grant (N/REF.: CE/GR/662/2013) within the framework of the Doctoral and Postdoctoral Fellowship Program "Eugen Ionescu" 2013/2014 set up by the Romanian Government.

\section{References}

[1] Batlle, I. and Tous, J. (1997) Carob Tree. Ceratonia siliqua L. International Plant Genetic Resources Institute, Rome, $92 \mathrm{p}$.

[2] Vekiari, S.A., Ouzounidou, G., Ozturk, M. and Görk, G. (2011) Variation of Quality Characteristics in Greek and Turkish Carob Pods during Fruit Development. Procedia-Social and Behavioral Sciences, 19, 750-755. http://dx.doi.org/10.1016/j.sbspro.2011.05.194

[3] Kumazawa, S., Taniguchi, M., Suzuki, Y., Shimura, M., Kwon, M.-S. and Nakayama, T. (2002) Antioxidant Activity of Polyphenols in Carob Pods. Journal of Agricultural and Food Chemistry, 50, 373-377. http://dx.doi.org/10.1021/jf010938r

[4] Würsch, P., Del Vedovo, S., Rosset, J. and Smiley, M. (1984) The Tannin Granules from Ripe Carob Pod. Lebensmittel- Wissenschaft und Technologie, 17, 351-354.

[5] Bravo, L., Grados, N. and Saura-Calixto, F. (1994) Composition and Potential Uses of Mesquite Pods (Prosopis pallida L.): Comparison with Carob Pods (Ceratonia siliqua L.). Journal of the Science of Food and Agriculture, 65, 303-306. http://dx.doi.org/10.1002/jsfa.2740650307

[6] Makris, D.P. and Kefalas, P. (2004) Carob Pods (Ceratonia siliqua L.) as a Source of Polyphenolic Antioxidants. Food Technology and Biotechnology, 42, 105-108.

[7] Marakis, S. (1996) Carob Bean in Food and Feed: Current Status and Future Potentials-A Critical Appraisal. Journal of Food Science and Technology, 33, 365-383.

[8] Avallone, R., Plessi, M., Baraldi, M. and Monzani, A. (1997) Determination of Chemical Composition of Carob (Ceratonia siliqua): Protein, Fat, Carbohydrates, and Tannins. Journal of Food Composition and Analysis, 10, 166-172.

http://dx.doi.org/10.1006/jfca.1997.0528

[9] Marakis, S., Marakis, G. and Lambraki, M. (1997) Tannins of Eight Carob Varieties from the Island of Lefkada, Greece. Chimica Chronica, New Series, 26, 57-66.

[10] Corsi, L., Avallone, R., Cosenza, F., Farina, F., Baraldi, C. and Baraldi, M. (2002) Antiproliferative Effects of Ceratonia siliqua L. on Mouse Hepatocellular Carcinoma Cell Line. Fitoterapia, 73, 674-684. http://dx.doi.org/10.1016/S0367-326X(02)00227-7

[11] Sakakibara, H., Honda, Y., Nakagawa, S., Ashida, H. and Kanazawa, K. (2003) Simultaneous Determination of all Polyphenols in Vegetables, Fruits, and Teas. Journal of Agricultural and Food Chemistry, 51, 571-581. http://dx.doi.org/10.1021/jf0209261

[12] Vekiari, A.S., Ouzounidou, G., Gork, G., Ozturk, M. and Asfi, M. (2012) Compositional Changes of Major Chemical Compounds in Greek Carob Pods during Development. Bulletin of the Chemical Society of Ethiopia, 26, 343-351. http://dx.doi.org/10.4314/bcse.v26i3.3

[13] Ahmet, M. and Vardar, Y. (1975) Chemical Composition of Carob Pods. Phyton, 33, 63-64.

[14] Papagiannopoulos, M., Wollseifen, H.R., Mellenthin, A., Haber, B. and Galensa, R. (2004) 
Identification and Quantification of Polyphenols in Carob Fruits (Ceratonia siliqua L.) and Derived Products by HPLC-UV-ESI/MSn. Journal of Agricultural and Food Chemistry, 52, 3784-3791. http://dx.doi.org/10.1021/jf030660y

[15] Arts, I.C.W. and Hollman, P.C.H. (2005) Polyphenols and Disease Risk in Epidemiologic Studies. American Journal of Clinical Nutrition, 81, 317S-325S.

[16] FAOSTAT (2012) Food and Agriculture Organization of the United Nations. http://faostat.fao.org/site/567/DesktopDefault.aspx

[17] Miliauskas, G., Venskutonis, P.R. and van Beek, T.A. (2004) Screening of Radical Scavenging Activity of Some Medicinal and Aromatic Plant Extracts. Food Chemistry, 85, 231-237. http://dx.doi.org/10.1016/j.foodchem.2003.05.007

[18] Madi, A. (2010) Caractérisation et Comparaison du Contenu Polyphénolique de deux Plantes Médicinales (Thym et Sauge) et la Mise en Evidence de leurs Activités Biologiques. Research Master, Mentouri Constantine University, Constantine, 109 p.

[19] Djeridane, A., Yousfi, M., Nadjemi, B., Boutassouna, D., Stocker, P. and Vidal, N. (2006) Antioxidant Activity of Some Algerian Medicinal Plants Extracts Containing Phenolic Compounds. Food Chemistry, 97, 654-660. http://dx.doi.org/10.1016/j.foodchem.2005.04.028

[20] Gaouar-Borsali, N. (2011) Etude de la Valeur Nutritive de la Caroube de Différentes Variétés Algériennes. Research Master, Abu BekrBelkaid University, Tlemcen, 95 p.

[21] Porter, L.J., Hrstich, L.N. and Chan, B.G. (1986) The Conversion of Procyanidins and Prodelphinidins to Cyanidin and Delphinidin. Phytochemistry, 25, 223-230. http://dx.doi.org/10.1016/S0031-9422(00)94533-3

[22] Rira, M. (2006) Effet des Polyphénols et des Tanins sur l'Activité Métabolique du Microbiote Ruminal d'Ovins. Research Master, Mentouri Constantine University, Constantine.

[23] Marakis, S., Lambraki, M. and Diamantoglou, S. (1993) Tannin Chemistry of Nine Cretan Carob Varieties. Chimica Chronica, 22, 213-224.

[24] Custódio, L., Fernandes, E., Escapa, A.L., Fajardo, A., Aligué, R., Alberício, F., Neng, N.R., Nogueira, J.M.F. and Romano, A. (2011) Antioxidant and Cytotoxic Activities of Carob Tree Fruit Pulps Are Strongly Influenced by Gender and Cultivar. Journal of Agricultural and Food Chemistry, 59, 7005-7012. http://dx.doi.org/10.1021/jf200838f

[25] Ouzounidou, G., Vekiari, S., Asfi, M., Gork, M.G., Sakcali, M.S. and Ozturk, M. (2012) Photosynthetic Characteristics of Carob Tree (Ceratonia siliqua L.) and Chemical Composition of Its Fruit on Diurnal and Seasonal Basis. Pakistan Journal of Botany, 44, 1689-1695.

[26] Benchikh, Y., Louailèche, H., George, B. and Merlin, A. (2014) Changes in Bioactive Phytochemical Content and in Vitro Antioxidant Activity of Carob (Ceratonia siliqua L.) as Influenced by Fruit Ripening. Industrial Crops and Products, 60, 298-303. http://dx.doi.org/10.1016/j.indcrop.2014.05.048

[27] Ahmad, M.H. and Abuerreish, G.M. (2012) Carob Fruit as Source of Carbon and Energy for Production of Saccharomyces cerevisiae. Jordan Journal of Biological Science, 5, 209214.

[28] Rababah, T.M., Al-U’Datt M., Ereifej, K., Almajwal, A., Al-Mahasneh, M., Brewer, S., Alsheyab, F. and Yang, W. (2013) Chemical, Functional and Sensory Properties of Carob Juice. Journal of Food Quality, 36, 238-244. http://dx.doi.org/10.1111/jfq.12033

[29] Şahin, H., Topuz, A., Pischetsrieder, M. and Özdemir, F. (2009) Effect of Roasting Process on Phenolic, Antioxidant and Browning Properties of Carob Powder. European Food Research and Technology, 230, 155-161. http://dx.doi.org/10.1007/s00217-009-1152-7

[30] Yousif, A.K. and Alghzawi, H.M. (2000) Processing and Characterization of Carob Powder. 
Food Chemistry, 69, 283-287. http://dx.doi.org/10.1016/S0308-8146(99)00265-4

[31] Abi Azar, R. (2007) Complexation des Protéines Laitières par les Extraits de Gousses Vertes de Caroubier: Propriétés technologiques des coagulums obtenus. PhD Dissertation, AgroParisTech, Paris, 195 p.

[32] Torun, H., Ayaz, F.A., Colak, N., Grúz, J. and Strnad, M. (2013) Phenolic Acid Content and Free Radical-Scavenging Activity of Two Differently Processed Carob Tree (Ceratonia siliqua L.) Pod. Food and Nutrition Sciences, 4, 547-553.

http://dx.doi.org/10.4236/fns.2013.45070

[33] Owen, R.W., Haubner, R., Hull, W.E., Erben, G., Spiegelholder, B., Bartsch, H. and Haber, B. (2003) Isolation and Structure Elucidation of the Major Individual Polyphenols in Carob Fibre. Food and Chemical Toxicology, 41, 1727-1738. http://dx.doi.org/10.1016/S0278-6915(03)00200-X

[34] Rakib, E.M., Chicha, H., Abouricha, S., Alaoui, M., Bouli, A.A., Hansali, M. and Owen, R.W. (2010) Determination of Phenolic Composition of Carob Pods Grown in Different Regions of Morocco. Journal of Natural Products, 3, 134-140.

[35] Roseiro, L.B., Duarte, L.C., Oliveira, D.L., Roque, R., Bernardo-Gil, M.G., Martins, A.I., Sepúlveda, C., Almeida, J., Meireles, M., Gírio, F.M. and Rauter, A.P. (2013) Supercritical, Ultrasound and Conventional Extracts from Carob (Ceratonia siliqua L.) Biomass: Effect on the Phenolic Profile and Antiproliferative Activity. Industrial Crops and Products, 47, 132-138. http://dx.doi.org/10.1016/j.indcrop.2013.02.026

[36] Bernardo-Gil, M.G., Roque, R., Roseiro, L.B., Duarte, L.C., Gírio, F. and Esteves, P. (2011) Supercritical Extraction of Carob Kibbles (Ceratonia siliqua L.). The Journal of Supercritical Fluids, 59, 36-42. http://dx.doi.org/10.1016/j.supflu.2011.08.007

[37] Henis, Y., Tagari, H. and Volcani, R. (1964) Effect of Water Extracts of Carob Pods, Tannic Acid, and Their Derivatives on the Morphology and Growth of Microorganisms. Journal of Applied Microbiology, 12, 204-209.

[38] Carvalho, M., Roca, C. and Reis, M.A.M. (2014) Carob Pod Water Extracts as Feedstock for Succinic Acid Production by Actinobacillus succinogenes 130Z. Bioresource Technology, 170, 491-498. http://dx.doi.org/10.1016/j.biortech.2014.07.117

[39] Khlifa, M., Bahloul, A. and Kitane, S. (2013) Determination of Chemical Composition of Carob Pod (Ceratonia siliqua L.) and Its Morphological Study. Journal of Materials and Environmental Sciences, 4, 348-353.

[40] Turhan, I., Tetik, N., Aksu, M., Karhan, M. and Certel, M. (2006) Liquid-Solid Extraction of Soluble Solids and Total Phenolic Compounds of Carob Bean (Ceratonia siliqua L.). Journal of Food Process Engineering, 29, 498-507. http://dx.doi.org/10.1111/j.1745-4530.2006.00078.x

[41] Meziani, S., Oomah, B.D., Zaidi, F., Simon-Levert, A., Bertrand, C. and Zaidi-Yahiaoui, R. (2015) Antibacterial Activity of Carob (Ceratonia siliqua L.) Extracts Against Phytopathogenic Bacteria Pectobacterium atrosepticum. Microbial Pathogenesis, 78, 95-102. http://dx.doi.org/10.1016/j.micpath.2014.12.001

[42] Youssef, M.K.E., El-Manfaloty, M.M. and Ali, H.M. (2013) Assessment of Proximate Chemical Composition, Nutritional Status, Fatty Acid Composition and Phenolic Compounds of Carob (Ceratonia siliqua L.). Food and Public Health, 3, 304-308.

[43] El Kahkahi, R., Zouhair, R., Diouri, M., AitChitt, M. and Errakhi, R. (2015) Morphological and Biochemical Characterization of Morocco Carob Tree (Ceratonia siliqua L.). International Journal of Biological and Medical Research, 6, 4946-4952.

[44] Makris, D.P., Boskou, G. and Andrikopoulos, N.K. (2007) Polyphenolic Content and in Vi- 
tro Antioxidant Characteristics of Wine Industry and other Agri-Food Solid Waste Extracts. Journal of Food Composition and Analysis, 20, 125-132.

http://dx.doi.org/10.1016/j.jfca.2006.04.010

[45] Benchikh, Y. and Louailèche, H. (2014) Effects of Extraction Conditions on the Recovery of Phenolic Compounds and in Vitro Antioxidant Activity of Carob (Ceratonia siliqua L.) Pulp. Acta Botanica Gallica: Botany Letters, 161, 175-181. http://dx.doi.org/10.1080/12538078.2014.909325

[46] Zam, W., Bashour, G., Abdelwahed, W. and Khayata, W. (2013) Simple and Fast Method for the Extraction of Polyphenol and the Separation of Proanthocyanidins from Carob Pods. Scholar Academic Journal of Pharmacy, 2, 375-380.

[47] Cavdarova, M. and Makris, D.P. (2014) Extraction Kinetics of Phenolics from Carob ( $\mathrm{Ce}$ ratonia siliqua L.) Kibbles Using Environmentally Benign Solvents. Waste and Biomass Valorization, 5, 773-779. http://dx.doi.org/10.1007/s12649-014-9298-3

\section{Submit or recommend next manuscript to SCIRP and we will provide best service} for you:

Accepting pre-submission inquiries through Email, Facebook, LinkedIn, Twitter, etc. A wide selection of journals (inclusive of 9 subjects, more than 200 journals)

Providing 24-hour high-quality service

User-friendly online submission system

Fair and swift peer-review system

Efficient typesetting and proofreading procedure

Display of the result of downloads and visits, as well as the number of cited articles

Maximum dissemination of your research work

Submit your manuscript at: http://papersubmission.scirp.org/

Or contact ajps@scirp.org 